\title{
Páscoa de neve de Enrico Testa
}

Patricia Peterle

Universidade Federal de Santa Catarina

\section{Resumo}

A tradução da poesia italiana foi muito importante ao longo do século XX, a partir de nomes que deixaram suas marcas e abriram um diálogo com outras culturas. É possível lembrar de Giuseppe Ungaretti, Eugenio Montale, Umberto Saba e também Andrea Zanzotto, Giorgio Caproni. A primeira década do novo milénio viu a circulação de uma série de antologias poéticas e de novos volumes de poemas. Neste ensaio, propóe-se uma leitura pontual de Páscoa de neve de Enrico Testa, a partir da publicação da edição brasileira em 2016.

\section{Palavras-chave}

- Enrico Testa · Páscoa de neve · Poesia Italiana · Tradução

\begin{abstract}
The translation of Italian poetry was very important throughout the 20th century, especially by some authorial names that left their mark and opened a dialogue with other cultures. It is possible to remember Giuseppe Ungaretti, Eugenio Montale, Umberto Saba and also Andrea Zanzotto and Giorgio Caproni. The first decade of the new millennium saw the circulation of a series of poetic anthologies and new volumes of poetry. In this essay, we propose a nuanced reading of Snow Easter by Enrico Testa, from the standing point of the 2016 Brazilian edition.
\end{abstract}

\section{Keywords}

· Enrico Testa · Páscoa de neve · Italian Poetry · Translation

- Professora de Literatura Italiana da Universidade Federal de Santa Catarina, pesquisadora do CNPq. Foi coordenadora do Programa de Doutorado em Literatura da UFSC e do GT de Literatura Comparada da Anpoll. Traduziu Giovanni Pascoli, Giorgio Caproni, Giorgio Agamben, Roberto Esposito, Ippolito Nievo, Enrico Testa, Eugenio De Signoribus. Possui ensaios e livros dedicados entre os quais: Fluxos literários (2013), Coleções literárias (2014), O homem e os animais (2014), No limite da palavra (2015), Arquivos Poéticos (2015), Vozes: cinco décadas de poesia italiana (2017). 
Desde o primeiro livro em 1988, a poesia de Enrico Testa foi bem acolhida tanto pela crítica quanto pelo público em geral. Para o leitor com maior intimidade com a produçáo italiana da segunda metade do século xx, basta lembrar os comentários feitos por nomes como Giorgio Caproni, Giovanni Giudici e, mais recentemente, Cesare Viviani. Poetas com os quais Enrico Testa possui e estabelece diferentes diálogos. Giorgio Caproni, voz emblemática para a poesia pós-Montale e um dos maiores poetas da segunda metade do século passado, é quem assina a apresentaçáo da primeira coletânea desse genovês, Le faticose attese (1988). Texto sagaz e sintético mas imprescindível para quem inicia a tatear seus versos. Nele Caproni, poeta e resenhista experiente, com um olhar afiado, identifica marcas significativas da escritura de Enrico Testa, o qual oferece ao poeta mais experiente agradáveis surpresas «numa terra de banais repetiçôes». Retomando uma expressão de Camillo Sbarbaro, Caproni diz ser a escritura de Testa poesie-poesie, como se dizia no período de escassez da guerra um café-café. Um dos verbos utilizados pelo poeta de Il seme del piangere, para se referir aos poemas recebidos é "gustare», ou seja, degustar, sentir, o que indica como esses versos captam a sua atenção e o contagiam.

Em 1994 e em 2001, Giovanni Giudici em dois curtos textos para L'Unità e Corriere della Sera pontua outros traços que destacam a poesia de Testa da imensa massa amorfa de poetas. Trata-se, na verdade, de duas pequenas e atentas resenhas para In controtempo (1994) e La sostituzione (2001), etapas necessárias no laborioso processo diante da folha em branco, que pouco a pouco vai sendo manchada de tons escuros (Giudici, 1994, 2001). Se na primeira, Giudici aponta para a bagagem herdada de Giorgio Caproni — presença sem dúvida impactante—e aponta para elementos próprios e singulares de Testa, colocando em evidência a paciência e a relação com a língua, na segunda, o poeta da Vita in versi destaca mais um traço fundamental, os fios da memória, um mosaico e suas tesselas, ruínas também de um tempo irrecuperável.

Ruínas sim, que podem lembrar a descrição benjaminiana do anjo da história, uma multidão de eventos que se misturam e entrecruzam como assinala outro poeta, Cesare Viviani (2004:21-24, 149-150)르, para quem o laboratório poético de Enrico Testa é lido como um «observatório lúcido e silencioso» das pequenas coisas que compóem a vida e sua cotidianidade. Poética também da perene fragmentariedade, ainda nas palavras do autor de La forma della vita, «a poesia de Testa é poesia do devir como para poucas outras foi». E continua Viviani, com grande precisão, «uma escolha radical, rara de se encontrar uma poesia em que cada representaçáo nasce e cresce em seu se fazer, em seu se evolver, não é precedida de nenhuma cena, de nenhuma ideia tida como matriz». Com efeito, desde o primeiro livro de 1988, os poemas de Testa parecem começar sem um início, como se os versos fizessem parte de um fluxo, de um movimento contínuo pelo qual o leitor passa, como se entrasse no meio do caminho desse fluir. Alguns indícios são justamente a ausência de títulos nos poemas (são poucos os que possuem um), a escolha por iniciar os primeiros versos sempre com letra minúscula e a exclusão do ponto final do último 
verso. Tais decisóes deixam rastros visíveis na forma e incidem na estrutura dos poemas, um movimento que pode espelhar o ir e vir da vida, ganhos e perdas, lembranças e esquecimentos, um oscilar que é inerente à palavra e à voz de Testa. ${ }^{2}$ Como afirma Viviani, «o movimento do sentido é o movimento da linguagem, que procede segundo um andamento não linear, totalmente imprevisível com suas conversôes, sobreposiçóes, desvios e distraçóes».

Um movimento circular que parece tender a Kairós, um tempo náo linear, cujo ritmo pode ser dado pelos eventos ou, melhor dizendo, pelas ocasióes. Uma explosão do tempo-de-agora (tempo cheio de agoras, para lembrar as teses benjaminianas), uma carga de tensôes, na qual também poderia estar uma morada do prazer, temporalidades, enfim, que impóem outra relação com o passado $e$ com o futuro $^{3}$. Questôes não distantes daquelas encontradas em alguns poemas de Murilo Mendes, em Cara ou coroa ou, por exemplo, em Pós-poema:

Não se trata de ilusáo, queixa ou lamento, / Trata-se de substituir o lado pelo centro. / O que é da pedra também pode ser do ar. / O que é da caveira pertence ao corpo: / Náo se trata de ser ou náo ser, / Trata-se de ser e não ser. (Mendes, 1994:432)

Nessa conjuntura, o presente, como aponta Benjamin, não pode mais ser visto como mera passagem ou transição, mas tempos nos tempos, pois nessa(s) articulação/óes está o ponto fulcral. É o experienciar do tempo, como evidencia e questiona Marc Augé, também por meio do exercício do olhar, um reaprender a sentir o tempo que escorre veloz. Por isso, toda e qualquer paisagem só existe por meio do olhar que a (re)descobre, é um espaço descrito por um homem a outros, como aponta ainda Augé (2004), no qual as palavras têm a capacidade de fazer ver, não apenas descrevem ou traduzem (Augé, 2004). É a capacidade de tocar a imaginação de outrem, as palavras caminham e vagam no e pelo corpo do leitor. Um caráter também aporético que é próprio da arte e, por conseguinte, da poesia. $\mathrm{E}$, aqui, estar atento às transiçôes, à fluidez presente ao redor é essencial para o articular da poesia de Testa:

Descartando, assim, o modo predicativo e náo respondendo mais ao princípio de náo-contradiçấo: uma coisa é isso e, ao mesmo tempo, não-isso. A poesia é, para mim, portanto, uma figura da aporia. E para 'tolerar' a aporia, a atençâo e a paciência são necessárias. (Peterle: 2014, 6).

O poema que abre essa coletânea traz vários dos aspectos assinalados até aqui:

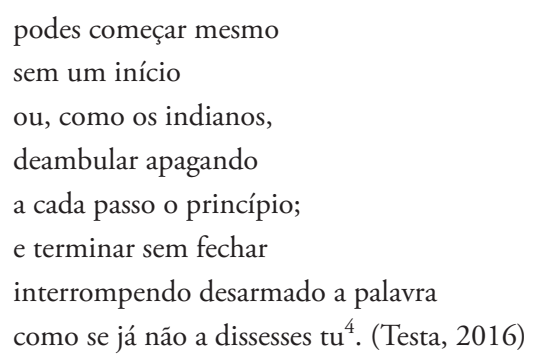

Nestas linhas está presente a "poética da calma» assinalada por Enrico Capodaglio (2010:127-130). As aspas 5 apontam para uma terceira voz no ato da fala, do que 
possa ter sido dito antes não se tem notícia: eis o leitor que entra no meio do fluxo assinalado acima. E o poema é encerrado sem um ponto final, só com o fechar das aspas; um possível comentário do interlocutor-leitor poderia estar presente na sua ausência, no espaço restante e branco da página. A circularidade, a movência das palavras e o jogo alquímico iridescente com que elas são experienciadas e articuladas colocam em questáo algumas categorias como a de origem e a de sujeito (Testa, 1999) ${ }^{6}$, por meio de uma dialética entre o dentro e o fora, mediada pelo contato. É nesse sentido que para Capodaglio o tempo presente é sentido como cruz e delícia do poetar de Testa. O primeiro verso de um dos poemas de Páscoa de neve indaga «quem mensurou o nosso tempo?» e o do poema seguinte diz «segue um moto fluído e vertical».

É, portanto, com esse movimento que se abre Páscoa de neve, volume que se inscreve no panorama da poesia italiana contemporânea e o marca definitivamente. Sáo ao todo 88 poemas, mais ou menos curtos, dialogantes com e infratores da tradição poética, divididos em nove seçóes: Os cães de Atenas, $O$ aniversário, Discurso do refém, Bálticas, Ismael, Tela de saco, Hammerwand, No Jardim Botânico, De outra forma. Há mais uma, mais ou menos na metade do volume, inserida depois de Bálticas e antes de Ismael, que é Cantiga da alvorada e contém um único poema, que é a tradução de Aubade de Ph. Larkin. Operação tradutória de relação com o outro, aproximaçáo do outro, de uma outra língua e apropriação ou antropofagia, no sentido que o Larkin nesse poema é o Larkin escolhido por Testa, lido por Testa, digerido e traduzido. Portanto, como em Ablativo, no qual há também esse mesmo movimento com outro poema de Larkin (The Mower), aqui temos a tensão que se estabelece entre Testa escritor de seus versos e Testa tradutor-escritor-apropriador dos versos de Larkin, que passam de algum modo também a ser seus. Náo se deve esquecer, contudo, que em 2002 o próprio poeta havia traduzido, sempre para Einaudi, High windows de Larkin. Como já dizia Lacan, no seminário dedicado à Carta roubada de Poe: «Os escritos carregam ao vento as promissórias em branco de uma cavalgada louca. $\mathrm{E}$, se eles não fossem folhas volantes, não haverá letras roubadas, cartas que voaram» (Lacan, 1998:30).

Versos impregnados de experiência, de sentimentos, de melancolia, clivados pela velocidade dos nossos tempos, pela fragmentaçáo da vida contemporânea, pelos contrastes entre humano-desumano, que náo deixam de esbarrar em questóes éticas e filosóficas. Se por um lado a linguagem pode ser considerada simples e os personagens eleitos, na maior parte das vezes, escolhidos em zonas familiares, pessoas próximas ao poeta, além de animais e plantas, a (re)leitura, a transfiguração e o trabalho com a própria língua tocam resultados poéticos não facilmente encontráveis. Eis aqui, sem dúvida, uma poesia de grande calibre e sensibilidade, capaz de tocar e deixar profundas marcas em quem a toca pela leitura.

Uma possibilidade é ver nesse volume um conjunto heterogêneo de dúvidas e inquietaçôes «coletados» ao longo de um caminhar. É o próprio Testa quem afirma, na entrevista já citada para a revista Subtrópicos, que «nessa trilha, escrever é um ir a pé, a paciência e a atençáo são essenciais». Palavras que podem lembrar as de Michel de Certeau, em $A$ invenção do cotidiano, quando diz «existe uma retórica da caminhada. A arte de moldar frases tem como equivalente uma arte de moldar percursos» e sobretudo «caminhar é ter falta de lugar. É o processo indefinido de estar ausente e à procura de um próprio» (De Certeau, 2000:179, 183). Um explorar e um expor-se à língua italiana acompanhados das mesmas açóes em relação ao 
tempo, seja este qual for, e aos espaços. Um ir e vir por territórios europeus da terra lusitana, amena e saudosa, aos Balcâs, com conflitos desarmantes. A calma, apontada por Enrico Capodaglio, aqui é mais do que necessária para captar sensaçôes e poder sentir e ver cores, odores, essenciais no contato e no contágio entre o dentro e o fora. Um amor pela vida que se dá também por seu reverso, pelo desalento e pelo desassossego. Uma lâmina afiada que corta e embaralha flashes cotidianos, lembranças recentes e remotas, e momentos coletivos e pessoais. É certamente uma poesia escavada na língua cotidiana, com incursóes na tradição, escavada no território áspero e dócil da sua parte lígure, espremida entre as montanhas e o mar, escavada nas leituras feitas e em imagens que retornam e são ressemantizadas. Diante dessa constelação, o sujeito segue andando e deixando para trás pedacinhos de si, vestígios desse «ir a pé», que pertencem ao sujeito, fazem parte dele, contudo não conseguem mais formar e dar conta de uma pressuposta totalidade. Imagem concretizada neste livro, em um dos escritos da segunda seção, $O$ aniversário, cuja característica é uma poesia-prosa aforismática, ou talvez resíduos de pensamentos e sensaçôes, restos de diálogos: «e o uso que posso fazer disso agora é, sob meu olhar amedrontado, o de quem destrói um mosaico para recompor, depois, com as mesmas tesselas uma figura nova e - meu deus! — totalmente diferente».

A questáo da origem é, portanto, central e aparece em mais de um poema da seçấo Os cães de Atenas: da passagem pela trilha que náo deixa vestígio à busca $\mathrm{e}$ à desilusão da origem das torrentes no período do verão. $\mathrm{O}$ último poema dessa parte pode por um lado pré-anunciar Bálticas, mas a potencialidade deste poema, de uma única estrofe com 37 versos, o mais longo de todo o livro, é a contraposição entre os espaços de dentro e de fora do mercado. Dentro, a riqueza genuína de todo e qualquer mercado, com suas cores, carnes, cabeças de cordeiro, carnes penduradas em ganchos, ricas vitrines, tecas ornadas com ossinhos e miúdos. Um ambiente que toca os sentidos de quem passa por entre as bancas com seus produtos, as mesmas bancas que nos versos seguintes protegem dos armados que vigiam a praça e do intenso e ensurdecedor tráfego. Um comércio também sonoro no qual se destacam a voz de tenor de um vendedor de pássaros e os acordes de três violinistas competindo. Nessa situaçáo, que pode ser vista como uma alegoria de tantas conjunturas, o eu do poema tenta falar com seus «caros companheiros sensitivos», mas eles não estáo mais ali, fugiram, desapareceram: «sumiram num instante / estarrecidos com tanto sangue». O contato com esse poema náo deixa o leitor imune; ele é chamado a refletir sobre a conjuntura delineada pelos versos, sobre a própria precariedade da condição humana. São 37 versos seguidos, sem pausa, que deixam respiração e fôlego no limite. Os tons roxos que abrem o poema e o nome de Francis Bacon evocado nos versos 6-9 («Agradaria ao pobre Francis, / feliz de se encontrar / entre quartos de carneiro em ganchos / e ossos e miúdos») podem inquietar ainda mais, se pensarmos nas possíveis pinturas às quais Testa faz referência. Poderiam ser elas Pintura (1946) e Figura com a carne (1954), que não deixam de trabalhar com situaçóes-limite, a solidão, a humanidade/desumanidade e, enfim, o que é recuperado pelo poeta, a imagem do homem como sendo também parte desses pedaços de carne, como os que estão descritos no início do poema.

$\mathrm{Na}$ já mencionada $O$ aniversário, a questáo central é a relaçáo com o passado, com os que dele fizeram parte e não mais estáo presentes. A voz da primeira composição anuncia, por meio de mais uma aporia, essa problemática da relação com os mortos: «É difícil vir até aqui para dizer que queres te incluir entre as coisas 
desaparecidas, enquanto te esforças em juntar uma coleção para impedir que as coisas desapareçam». Tormento e conforto sáo duas palavras-chave para essas páginas, que conservam um dos momentos mais sensíveis que fazem referência à morte de uma pessoa amada. Como os demais desta parte, esse também é introduzido pelas aspas:

De noite, uma matilha de cães no quarto, ao redor da tua cama: antes irritados pela brancura que cai sobre as paredes... quase enraivecidos... depois sempre mais calmos; um gemido de afeto e tristeza. O sonho acaba quando estáo lambendo a minha mão que aperta a tua que segue precipitando no gelo.

Afeto, tristeza, perda, alívio, dor, sofrimento, vida e morte fazem parte do caminhar, deste andar junto, que é também um andar descompassado, tentativas de encontrar-se desencontrando-se (Testa, 2010) 7 . De fato, a separação é outro campo central em Páscoa de neve, quarta coletânea de Testa, que reúne núcleos caros e essenciais, que retornam também em Ablativo. Um termo de benjaminiana memória capaz de amalgamá-los é ruina: ruína das relaçóes, ruína de um mundo (ou mundos), ruína dos tempos idos, ruína ainda como o que resta da lembrança, ruína da própria língua. Enfim, articulaçóes entre vida experienciada e gestos do cotidiano, entre espaços familiares e outros estranhos, mas que podem ter algum aspecto familiar, que estimulam as reflexóes e as andanças do poeta e do seu poetar.

Discurso do refém, a terceira seção, é um momento especial do livro, no qual certa intimidade do poeta se mistura com algumas reminiscências. Aqui, os versos divididos em duas estrofes se abrem com a imagem da costa que rispidamente acaba no mar «apoiado em cadentes encostas», paisagem característica dessa parte da Ligúria, acompanhada pela flora mediterrânea, o pilriteiro ou espinheiro-branco. Mas a ameaça não acaba, pois o eu retrocede entre armadilhas e bocas de lobo, e o oximoro se concretiza no segundo verso da segunda estrofe na luminosa corrente sem luz. Espaço de beleza e, ao mesmo tempo, de ameaça. Numa outra composição, a esfera familiar, a parte mais íntima da casa, com seus hábitos cotidianos, vem à tona, na descrição do ato de fuçar e pelos barulhos, o arrastar das cadeiras, o fechar das gavetas, o ruído da louça... Um cruzamento de planos e atmosferas segue sendo delineado, em mais um espaço aporético, no qual as rolinhas de bronze do cemitério parecem ter vida e bater asas. Ou, como num outro poema, «só uma memória avara e seca, / onde, à noite, brilha / para além dos anos, / longínqua minha alegria, / como entre a pérgula farta / a lua». Atmosfera quase onírica, lembrando da importância do sonho, que retorna no poema final do livro, que se abre com a imagem imponente dos castanheiros da Índia, com suas flores, majestosas em forma de penachos, e outras plantas que seguem invadindo os espaços da repentina primavera. Ao lado deste rico renascimento, o bando de garotos que passa cantarolando e "os batentes bambos podres de maresia...», mais uma ruína acompanhada de um «deixe-me estar» explicitado na última estrofe.

Ruínas também da e na língua que se concretizam na inversáo de alguns ditos populares ou de formas mais cotidianas. E Testa vai ainda mais além nesta seção, há aqui um exemplo de como as pesquisas e a atividade do professor e pesquisador tocam o poeta. Ao tratar da língua escrita dos semicultos, entre o século XIX e o xx, num capítulo de Litaliano nascosto (2014), o professor de História da Língua toma como exemplo uma experiência de radical marginalidade. $\mathrm{O}$ testemunho 
de um soldado, Antonio D., proveniente de Rovigo, internado em setembro de 2015 no hospital psiquiátrico de Gênova Quarto, com alta no mês de junho do ano seguinte. Para além das questóes mais específicas e técnicas que chamam a atenção do estudioso e linguista, na parte final da carta enviada aos pais do manicômio, há algo que toca Testa-poeta. E é, justamente, o fato de essas últimas linhas porem em cena temas, sentimentos e conteúdos humanos cuja profundidade ecoa nas esfarrapadas vestes expressivas. Esse momento que contagia a leitura do poeta é marcado por um entrecruzar em que a fragilidade da língua corresponde

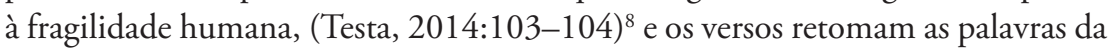
carta de Antonio D., reproduzida no volume ensaístico.

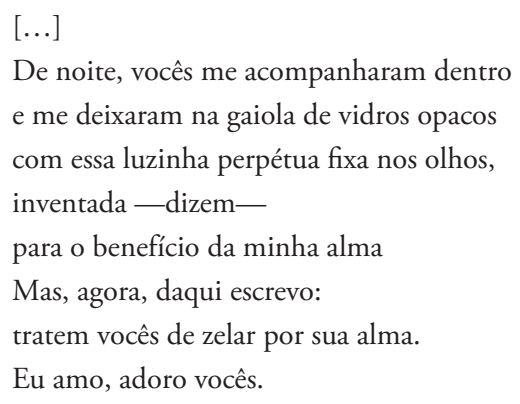

Bálticas, que também é evocada em Ablativo, obviamente recupera uma região de conflitos e tensóes num leque de diferentes cenários, Marselisborg com o ciciar raro das bicicletas; Aarhus em que o olhar do poeta flagra um canal, na «orbita saturnal da cidade»; a igreja que hospedava loucos, pobres e adoentados, a luminosidade e as cores do céu já descobertas nos quadros dos pintores, tudo acompanhado da advertência de que não é necessário levantar muito os olhos, basta prestar um pouco mais de atençáo para além da cerca do aeroporto. Não há como escapar de uma espécie de acerto de contas ético, mesmo que seja entre eu e eu(s):

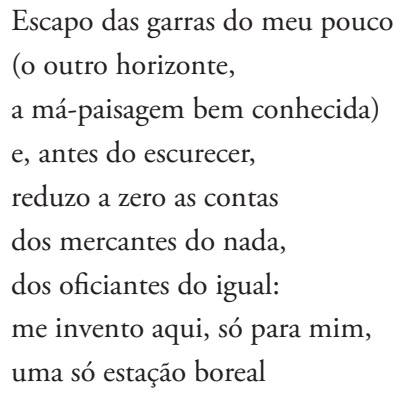

É a arte de escavar que é acionada e colocada em jogo e o observar é mais do que uma açáo necessária e vital. Um ir e vir pela existência sempre ameaçada, como a imagem da navalha que desce acariciando as costas em uma página de $O$ aniversário, última seção antes do «intermezzo» de Cantiga da alvorada, exercício de leitura, de tradução, sobretudo um exercício de alteridade. Limiar e soleira talvez sejam dois termos que, de algum modo, possam dar conta desta significativa experiência no panorama contemporâneo da poesia italiana. Assim, se de um lado ele é tipicamente genovês, muito ligado à sua pequena parte da Ligúria (basta pensar no 
amplo leque de plantas, flores e nas várias referências que povoam os versos), de outro, como um movimento contrastante e complementar, há o gesto de explorar outros territórios, que pouco a pouco passam a rodear espectralmente o íntimo e o familiar'. E, nesses deslocamentos de provocantes fissuras, o ato de rememorar faz-se essencial, tornando-se vital, uma forma de sobrevivência.

Percepção e esquecimento, abalos na experiência e no experienciar a própria língua no movimento marcado pelo deslocamento provocado pela tradução. Como apontou Paul de Man, na leitura de "A tarefa do tradutor» de Walter Benjamin, o movimento de disjunção é o pré-requisito de uma leitura crítica. Separação que deixa fraturas, rastros mais ou menos melancólicos, e que fazem da «perda» um elemento central e potencializador. Ruínas da leitura que sobrevivem nas açóes de destruição, decomposição e reconstrução, inerentes ao processo da traduçáo. O nome e a escolha por traduzir Philip Larkin não devem causar estranhamento para o leitor. Enrico Testa é um atento leitor de Larkin, com quem compartilha o "caráter ordinário da existência», a "análise do cotidiano e dos seus mínimos detalhes», como ele mesmo escreve no prefácio a High Windows. Ao falar da poesia do autor de Aubade, Testa parece estar falando sobre as suas próprias escolhas poéticas. Outros pontos que aproximam os dois autores concernem à opção por uma língua antirretórica, permeada de elementos narrativos, um poema de maleabilidade plástica que toca prosa e poesia além, é claro, das duras, ácidas e amargas reflexôes. A tradução de Aubade, em italiano Canzone d'alba, em português Cantiga da alvorada, é mais um indício, ou, se se preferir, uma assinatura, da conjunção múltipla e plural que incide na escritura deste poeta italiano. Tradução, reescritura, escrita poética constituem, à primeira vista, alguns dos gestos nesta imbricada trama entre línguas. $\mathrm{O}$ texto da traduçáo para o italiano do poema de Larkin oferece pontos importantes para um debate sobre as tensões do processo tradutório, incluindo as escolhas/modificaçóes aportadas por Testa (poeta-tradutor e tradutor-poeta), embora esta nấo seja a sede mais apropriada para tal discussão. No entanto, vale a pena ressaltar alguns aspectos como a pontuaçáo, que sofre mudanças importantes e acaba por se aproximar bastante do poetar de Testa, o número de versos que aumenta, deslocamentos e inversóes que fazem parte e testemunham o acirrado confrontar-se e o jogo com o texto de outrem. Um percurso do poeta, do crítico, do tradutor que não deixa de perpassar pela experiência de autores que lhe são também caros como Eugenio Montale, Giovanni Giudici, Franco Fortini, Giorgio Caproni e Vittorio Sereni.

Com Páscoa de neve, a sexta seção que dá o título ao livro, é retomada a scrittura in proprio. Porém, a presença do(s) outro(s) não se apaga, se mistura com as recordaçôes e nenhum dos seis poemas aqui é introduzido pelas aspas, táo frequente em outros momentos. A ideia da disjunção parece dominar a atmosfera destas páginas, em variadas situações, desde um desenho de criança, deixado no bolso do casaco e depois queimado, até uma tentativa de reencontro mesmo à distância, por meio de um telefonema do Belvedere, em Viena, que acaba caindo na secretária eletrônica com a voz que escorre e escava na «caligem pascoal». Folhas, ventos, verbos onomatopeicos seguem perfilando esta escritura e a seção termina num tópos (talvez herança caproniana) da poesia de Testa, a estação ferroviária. Duas estrofes, a primeira foca o mato, os troncos das acácias molhados depois da chuva, e a segunda capta os resíduos da Páscoa, passagem e celebração, que se foi e o que resta é a sensaçáo desoladora. Da grande festa restam as tiras pendentes 
do papel de alumínio dos ovos nos ramos das cerejeiras, «que deveriam manter à distância / a intrometida nação dos melros». Disjunçấo também presente na expressão Páscoa de neve, na qual a redenção aparece fria, sem tons de confissão ou de lamentaçôes, uma visão certamente trágica (talvez catastrófica), mas que não segue na direção fatal e vazia do abismo (Peterle, 2015, 69-85). Como bem apontou Fabio Moliterni (2011:298-302), o diálogo travado com o leitor não é nem um momento consolador nem garantia de algo. No jogo iridescente com a língua, no qual cotidianidade, plasticidade e mobilidade são elementos importantes nesta imbricada teia de encontros e desencontros, que escavam na experiência — por via da memória, do sonho, da recordaçáo-, vão sendo inscritos vestígios e rastros de uma vivência que parece a todo tempo se questionar.

Ismael, além de "(Isaías 53)» em Discurso do refém, é outra referência bíblica neste percurso, como está inscrito no poema que traz a presença de sua mãe Agar, a escrava egípcia de Abraão, com quem este teve Ismael. Nesses versos, a fragilidade da existência talvez seja o ponto central, no qual é possível se dar conta de "como somos todos / violentamente perdidos». Inclusive uma brincadeira inocente de criança, a amarelinha, tem o seu reverso no estrago que pode provocar «destruindo vidros e flores»; ou ainda uma voz que fala a um filho que morreu, mais uma situação de perda e um cirandar profundo que resta na memória, reconhecível no mover-se das răs. A rudeza da existência, a lei «selvagem» da vida, traz uma imagem de grande força, no poema que inicia com «a veste do corvo». Exatamente isso do corpo e da carne para uma veste esvaziada — literalmente uma carcaça—, pois sob a bela rosa canina, formigas e insetos vorazes, como se estivessem em passo de guerra, retiram e consomem a carne. Ação devoradora que por uns instantes parece ser aliviada pela passagem de uma sombra sobre o «desgrenhado floco» que une «o rastro mineral do olho / ao céu imêmore / e à nuvem que escorre». Um olhar que poderia recordar o de Murilo Mendes, em Ipotesi, livro escrito diretamente em italiano, cuja quinta seçáo, Città, inicia com:

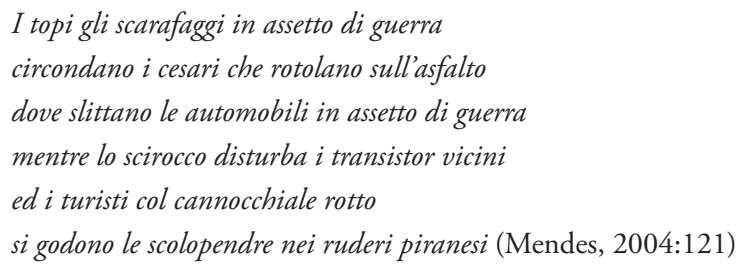

Essa coletânea traz um campo semântico assinalado no título pela palavra «neve», que se desdobra em termos como «fria», «frio», «frios», «friaca», usados sete vezes; "gelo», com seis ocorrências e "congelado", utilizado em duas ocasióes. Além disso, a cor cinza predomina em alguns cenários com uma incidência de cinco usos, não se distanciando de outra cor que é o preto-verde ou o branco da névoa. Essa, com certeza, não é uma palheta qualquer: os tons acromáticos ecoam pelo menos dois poetas fundamentais no percurso poético de Testa, Giorgio Caproni e Paul Celan.

Tela de saco, que faz referência à trama do tecido tosco, a seção mais longa, subdividida em duas (I e II), continua o passo por entre recordaçóes e experiências. Savona, Sant'Ilario, Gênova são alguns topônimos reconhecíveis por meio das pistas nos versos: Salita Inferiore Salvator Rosa, Via Rio Fontanino, Piazza Acquaverde, onde há a estátua de Colombo na frente da estação de trem Príncipe. O dramático 
sentimento da separação bate às portas do exílio, «da partida / e argila e salmo/ na tela de saco / do exílio", como registra o último verso do primeiro poema. Lembranças e heranças que nos "perseguem", nos são passadas sem um aceite $a$ priori e começam a fazer parte de uma esfera mais íntima. Tal afirmação serve tanto para se pensar o diálogo com a tradição poética, inclusive a mais recente, como para se pensar as coloridas barrinhas de Marselha e o arsenal de instrumentos de corte (diferentes tipos de tesouras e de facas) descrito num dos poemas mais tocantes, em que o poeta se abre, expóe certa intimidade, abre uma das portas de parte da sua casa: «É contudo a herança de vocês / de dedicação, manias e ofícios, / que me deixaram nesta veste estranha», com a sensação contrastante de que "Tudo isso me dá o sentido e a consciência de não poder nunca mais voltar para casa».

Hammerwand é outro topônimo que aponta para o cenário das encantáveis Dolomites, mais especificamente para a região do Trentino Alto Adige, os Alpes de Siusi também são outra provável referência familiar. A flora toma conta dos versos, damas-nuas, erice aná, lariços, veratro ou flor da verdade, arminho, samambaias, rosas, líquenes e, como não poderia faltar, no meio de todo esse verde, a clareira e «o véu matutino da névoa [...] na montanha». E ainda, unindo os últimos versos de dois poemas: «Sem nome nem origem: / pertos de uma graça / de primeiro grau» e «uma paisagem, ágil e mortal, / para um possível destino dual». Das Dolomites para a terra lusitana, com a colina do Restelo, o Jardim Botânico na Rua da Escola Politécnica, o conhecido Rossio. Espaços de Lisboa, cidade melancólica, nostálgica e saudosa, cara a Enrico Testa, como se percebe também pelas linhas a ela dedicadas em Ablativo.

A seção que encerra Páscoa de neve, De outra forma, parece, pelo título, tentar apontar para outros caminhos, contudo a peregrinação continua. Viena, Belgrado, Londres, Rio Mondego, em Coimbra, e outros espaços mais ou menos conhecidos são trazidos como num movimento cíclico, permeado de palpitações, «Voltamos atrás / retomamos do início». É um desdobrar-se sobre a própria escritura, sobre a própria vivência e ainda sobre o laboratório da escritura, sem cair em exercícios retóricos e oraculares. Uma prática da atenção e da observação que espreita, indaga e nos coloca frente a frente a diferentes esferas individuais e coletivas da vida, que por sua vez impelem obrigatoriamente reflexóes éticas, incluindo as mais singelas. A sensaçáo talvez seja a descrita na traduçáo de Larkin «E assim resta, exatamente na borda da visão, / uma pequena mancha desfocada, / uma sensação de frio obstinada / que freia qualquer impulso na indecisão». Uma montagem de planos que absorve léxico e métrica, da mais familiar àquela de cunho literário, fragmentos e resíduos impregnados de sentimentos e contatos, que testemunham o árduo e generoso exercício de Enrico Testa. Desencanto, enfim, outro termo útil para se pensar nesta complexa trama poética aberta em Páscoa de neve, que encontra nos fios ralos, na teia desbotada, gasta e desfiada, que vai se esgarçando ainda mais, tons e ritmos próprios.

Para finalizar, ao tratar da urdidura de Testa é importante destacar, mesmo que rapidamente, alguns contatos e contágios com outros escritores que se escondem nesse poético alinhar das palavras. Algumas pistas estão nas Notas, fornecidas pelo próprio poeta, mas há outras náo reveladas, que passam a fazer parte dos jogos e movimentos da leitura. Para além de nomes que náo poderiam ser dispensados quando se trata de Enrico Testa, como os mais conhecidos Giovanni Pascoli, Eugenio Montale, Camillo Sbarbaro, Giorgio Caproni, Vittorio Sereni, Giovanni Giudici, 
podem ser pescados em seus versos, com uma atenta leitura, por exemplo, referências a um dos contos dos Irmãos Grimm, a outro célebre texto da literatura infantil como $O$ vento nos salgueiros de Grahame («um rato d'água às voltas com o Grande Mundo»), mas, tendo em vista que não é possível aqui referenciar todos esses jogos de intertextualidade e de contaminaçóes, gostaria, para concluir, de pelo menos chamar a atenção para uma provável coincidência, que está na segunda estrofe, do sexto poema, da seçáo Discurso do refém, em que se faz presente uma voz feminina.

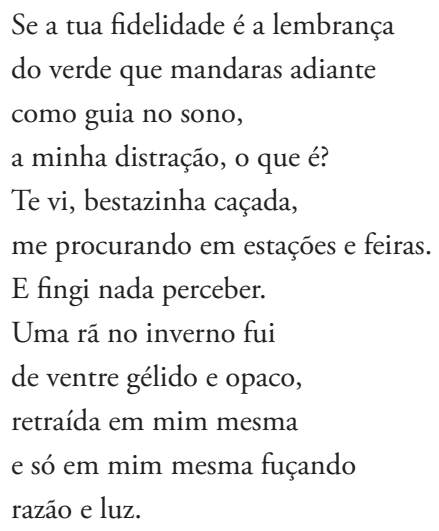

Algumas perguntas que emanam deste volume certamente estấo relacionados a questôes que vão além da própria poesia, mas que por meio dela (da poesia) podem ser tocadas e exploradas. Não se trata, portanto, somente de uma experiência que se faz, mas de uma experiência que faz ser, para lembrar Jean-Luc Nancy, outro nome recorrente nas leituras de Testa. Os versos indicados acima podem, pelos termos escolhidos, lembrar um fragmento de Primo Levi:

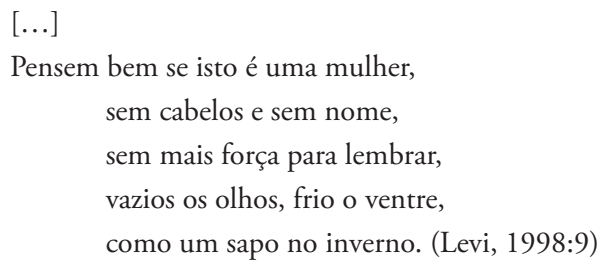

Sem dúvida, a conjunçáo e o momento ao qual se faz referência não são e nem poderiam ser os mesmos. Por outro lado, é praticamente impossível que Testa não o tenha lido. Resquícios de leituras? Caminhos tortuosos da própria literatura? Provavelmente sim, leituras e releituras, termos e expressóes que seguem se sobrepondo e conquistando outros lugares e constelaçôes. Uma escuta que só se dá no encontro com a língua, e a escritura do poeta genovês é fruto de encontros e de relaçóes. A estrofe que antecede e a que vem depois do fragmento entre aspas já sinalizam para as diferenças intrínsecas. Um ponto dialogante poderia ser o da memória, mas também aqui esse aspecto é recuperado e trabalhado a partir de diferenças, a da própria experiência, e de diferentes singularidades. Um fazer parte da mesma língua, fazer uso das mesmas ferramentas, não impede a abertura de outras vias e trajetórias. Nessa linha, é possível dizer que o sentido é dado, doado, abandonado, anunciado e, sobretudo, partilhado. Um partilhar, portanto, de 
vozes em que cada uma possui a sua expressão singular, assinaturas ou indícios, ao mesmo tempo em que já anuncia uma terceira, a voz do outro (Nancy, 1993).

Depois de tantas palavras, talvez uma possa servir para encerrar, mas sem colocar um ponto final, já que a leitura nas suas misteriosas e mirabolantes contorçôes continua no e pelo corpo do leitor. Essa palavra é silêncio, entendido náo como a interrupçáo do comunicar, mas, ao contrário, como o que torna possível o próprio comunicar e tudo o que concerne a esse gesto. Aqui está a importante tensáo colocada na complexa trama da poesia de Testa, que pode ainda ser lida como uma resistência entre palavras, pausas e silêncios: «vazio de palavras, permitido pela relação, sobre a qual crescem o sentido e a palavra em si» (Testa, 1996:27). A voz delicada e sensível fala de temores, angustias e anseios, sem deixar de ser precisa e firme. Talvez, por isso, pensando nas idas e vindas das relaçôes (passagens, laceraçôes, melodias, encontros, despedidas, trânsitos), elemento essencial e fundamental de qualquer existência, Páscoa de neve possa ser ainda lido como um intenso testemunho de amor e amizade («Com o abraço houve um silêncio / que tirou peso ao mundo»).

A tradução de poesia é um desdobrar-se do embate com as línguas, suas impossibilidades, uma complexidade que se dá por meio da/na língua, e refletir sobre esse processo, sobre as escolhas e decisões tomadas, não é fácil. É um processo melancólico, de luto, para lembrar Paul Ricoeur ou o poeta mexicano Xavier Villaurrutia, inscrito na tensão entre a possibilidade-impossibilidade-necessidade. Forças diversas inerentes ao ato em si que devem dar conta de uma série de variáveis como, por exemplo, o «legame musaico» tratado por Dante no Convivio, que coloca uma questáo central ao pensar na estrutura e nas suas relaçôes intrínsecas com o conteúdo, que nem sempre é possível manter na tradução. Tendo em vista esta e outras questōes desafiadoras e ameaçadoras, dadas pela própria experiência como poeta e tradutor, Marco Lucchesi afirmou ser a tradução literária uma arte de naufragar com dignidade (Lucchesi, 2006:207).

Um processo sanguinolento? Talvez sim. Um corte no texto de partida, uma ferida que na medida em que as negociaçóes iniciam vai sendo aos poucos cicatrizada. Todavia, a marca do corte, a cicatriz, náo desaparece, permanece ali inscrita como um indício. Nesse sentido, o texto traduzido pode ser visto como um arquivo tanto pessoal do tradutor como coletivo das tensóes entre tradutor, texto e autor (Peterle, 2013:97-112). Assim, traduzir é arriscar-se, mas é também estar disponível para dar-se ao outro e escutar a voz de outrem, acolhendo os obstáculos deste confronto nada pacífico. As múltiplas dobras desta relação delineiam um movimento que sai de si, se depara com uma língua outra, retorna para si numa língua terceira, estranha, encontrada no limiar.

Em termos mais específicos, o trabalho de tradução dos poemas de Enrico Testa é laborioso. O texto seduz, estimula leituras e releituras que fazem com que se torne difícil e doloroso colocar o ponto final. O embate com o texto ecoa no embate do leitor consigo próprio. Em relação à estrutura, no mais das vezes é usada a forma livre entremeada de elementos da tradiçấo e de algumas «liberdades poéticas» que deixam ainda mais árdua a tarefa tradutória. Em primeiro lugar, tentou-se preservar o ritmo, as calibradas rimas e o tom coloquial da escritura. Uma observação a ser feita é que, quando no texto em italiano há o uso da segunda pessoa, na tradução em português ora optou-se pela segunda pessoa «tu» ora pelo "vocề" para manter 
o tom coloquial e também para usar e explorar essa variedade que a língua de chegada oferece. Sempre que possível foi mantido o uso frequente de verbos onomatopaicos, que não deixa de ser uma herança pascoliana. Toda a gama de vocábulos que se referem a animais, flores e plantas foi mantida, nenhum termo sofreu adaptação ou domesticação, talvez por isso alguns nomes podem soar estranhos, mas tendo em vista que se trata normalmente da vegetaçáo de tipo mediterrânea (também presente em outros livros, como Ablativo) optou-se por mantê-los. Na poesia de Testa é difícil encontrar termos genéricos, há uma precisão na escolha e no uso desse vocabulário; de fato, tais palavras apontam para uma escolha precisa que reafirma a não ornamentalidade desta poesia. Operaçóes como inversóes de palavras no mesmo verso, substituiçóes e trocas podem ser encontradas e foram utilizadas ao longo da reescritura de Páscoa de neve. Sem essas ferramentas o trabalho poderia ter sido mais sangrento. Agora, as dúvidas, as reticências e as feridas abertas aparentam ter desaparecido e essa harmoniosa publicação carrega consigo resíduos e marcas restantes. 
"scelta" del manicomio ("che io sono in paradiso e mi volete trassinar al inferno"), il dialogo con figure che non riusciamo a identificare altrimenti se non come umbrae ("io son cui con mio zio rafaele conl nono col marito della zia teresina e con tanti, altri che me la passo bene"), la coscienza della propria anima e l'invito a ognuno a prendersi cura della propria ("amè melano gia curata lanima, ora pensateci curarvela voi"), la semplice comunicazione del proprio affetto ("io vi amo vivolio bene"). Se c'è un momento in cui l'escussione linguistica, compiuto il suo dovere, deve poi arretrare di fronte a un testo, è proprio questo: quando ci s'imbatte in un reperto che mette in scena temi, sentimenti e contenuti umani la cui profondità è un tutt'uno con la sbrindellata veste espressiva e il cui tenore vocale si fa veicolo estremo e quasi semicatombale della densità antropologica e storica del dire» (Testa, 2014:103-104).

${ }^{9}$ Outro exemplo desse movimento é a seção Breve excursão pela América do Sul, em Ablativo (Testa, 2014).

\section{Referencias bibliográficas}

Agamben, G. (2005). Infância e história [Trad. Henrique Burigo]. EDUFMG.

AugÉ, M. (2004). Rovine e macerie - il senso del tempo. [Trad. Aldo Serafini]. Bollati Boringhieri.

Capodaglio, E. (2010). La poetica della calma di Enrico Testa. istmi, (25-26), 127-130.

Cortelessa, A. (2006). Enrico Testa, sé come un altro. En La fisica del senso - saggi e interventi su poeti italiani dal 1940 a oggi (pp. 528-533). Fazi Editore.

De Certeau, M. (2000). A Invenção do Cotidiano 1 - Artes de fazer [Trad. Ephraim Ferreira Alves]. Editora Vozes.

Giudici, G. (1994, 12 de septiembre). Versi in controtempo. L'Unità. Giudici, G. (2001, 1 de septiembre). Testa: rime alla deriva. Corriere della Sera.

LACAN, J. (1998). O seminário sobre "A carta roubada». En Escritos [Traducción Vera Ribeiro]. Jorge Zahar.

Levi, P. (1998). É isto um homem? [Trad. Luigi del Re]. Editora Rocco. Lucchesi, M. (2006). Meridiano celeste \& bestiário. Record.

Mendes, M. (2004). Ipotesi. Stegagno Picchio, L. [org.]. Zone Editrice. Mentes, M. (1994). Poesia Liberdade. En Poesia Completa e Prosa. Editora Nova Aguilar.

Moliterni, Fabio (2011). Pasqua di neve di Enrico Testa. En Il vero che è passato. Scrittori e storia nel Novecento italiano (pp. 298-302). Edizioni Milella di Lecce Spazio Vivo.

NANCY, J.L. (1993). La partizione delle voci-verso una comunità senza fondamenti. Il poligrafo.

Pestarino, R. (2015). La poesia di Enrico Testa. Mosaico. XiII(137), 28-30. Peterle, P. (2013). Possíveis percursos no babélico labirinto da literatura italiana traduzida no Brasil. En Peterle, P; Santurbano, A. Wataghin, L. 
[Orgs.]. Literatura Italiana traduzida no Brasil (1900-1950). Comunità. Peterle, P. (2014). Poesia aporética - entrevista com Enrico Testa. En Subtrópicos, (11), 6.

Peterle, P. y Santi, E. (2015). O fio das relaçôes humanas. Anuário de Literatura (20.2), 31-37.

Peterle, P. (2015). Outra via: vivo all'ablativo - percursos na poesia de Enrico Testa. En no limite da palavra (pp. 69-85). Letras.

Raffaeli, M. (2011). Disincanto in grigio. En Bande à part. Gaffi. Testa, E. (1996). Pronomi. Il Segnalibro.

Testa, E. (1999). Per interposta persona - lingua e poesia nel secondo Novecento. Bulzoni Editore.

TESTA, E. (2009). Eroi e figuranti - il personaggio del romanzo. Einaudi. Testa, E. (2010).«Prefazione». En Vigevani, A. L'esistenza - tutte le poesie 1980-1992. Einaudi.

TeSTA, E. (2014). L'italiano nascosto. Einaudi.

Testa, E. (2016). Páscoa de neve [Trad. P. Peterle]. Rafael Copetti Editor. Testa, E. (2014). Ablativo. [Trad. P. Peterle]. A. Santurbano, S. de Gaspari. Rafael Copetti Editor.

Viviani, C. (2004). La voce inimitabile - poesia e poetica del Secondo Novecento. Il Melangolo.

Zublena, P. (2005). Enrico Testa. En Alfano, G; Baldacci, A.; Cortellessa, A. et al., Parola Plurale - Sessanquattro poeti italiani fra due secoli (pp. 559-573). Sossella. 